

\section{Bare-Metal Stents}

Bare-metal stents were the first generation of carotid stents. They helped relieve the decrease in luminal diameter after angioplasty effectively. However, every material has its specific characteristics.

\section{Stainless Steel Stents}

Within the family of stainless steel stents, the 316L stainless steel stent is the most common one. 316L stainless steel has been one of the first materials to be used in carotid stenting. It is composed of chromium, nickel, molybdenum, manganese, silicon, carbon, phosphorus, sulfur and iron [10]. Stainless steel can be used in both balloon-expandable and selfexpanding stents. It can be easily deformed when in its fully annealed state, which is of key importance for balloon-expandable stents. On the other hand, it has enough elasticity when fully hardened to serve the concept of self-expanding stents. Stainless steel is a strong material with a high radio force; therefore it may prevent the abrupt closure of a vessel, in addition to having a good biocompatibility and being safe for the human body. It has been the gold standard for stents other materials [11].

Stainless steel stents have been used successfully in many cases. Mukherjee et al. [12] assessed 178 patients in their study. Of these 178 patients, 89 received stainless steel stents and 89 received nitinol stents. At 6 months' follow-up, there were no differences in the incidence of stroke (3.3 vs. $2.2 \%$ ) between the stainless steel stent group and the nitinol stent group. However, the mortality rate of the stainless steel stent group was higher than that of the nitinol stent group, but there were no neurological deaths in either group. This proved that stainless steel stents are as safe as nitinol stents.

Having been the first material to be introduced to the field of stenting, stainless steel still causes many problems which need solving: they have a low MR compatibility, they are more likely to induce vessel wall injury [13] compared with nitinol stents, they have a low corrosion resistance and a bad vessel wall-stent apposition, and they release metal ions [14] inducing inflammatory and cell apoptosis. These issues need to be resolved.

\section{Cobalt Alloy Stents}

Cobalt alloy is another material used in carotid stents, usually in balloon-expandable stents. It is composed of cobalt, chromium and other metal elements. Compared with 316L stainless steel, cobalt alloy is stronger and has a higher radio-opacity. These properties make thinner stent struts possible [15]. Thinner struts, on the other hand, make the device more flexible and reduce the stent's cross-sectional diameter. Additionally, thinner struts have been proven to lead to a reduced restenosis rate. With their inherent corrosion resistance, acceptable vessel wall-stent apposition [16] and good biocompatible properties, cobalt alloy stents acquired a more and more important role in CAS.

Vajda et al. [17] analyzed 25 patients (30 lesions) in their study, using balloonexpandable cobalt chromium stents (Coroflex Blue). All procedures were successful. As many as 29 out of the 30 lesions ( $97 \%$ ) met the standard of residual stenosis of $<50 \%$. Of the 30 procedures, 28 were uneventful; however, the CAS led to 1 transient and 1 permanent neurological deficit in the remaining 2 cases. All patients were followed up with an angiogram after a median of 15.2 months. There, the authors noted a recurrent stenosis rate of 11 out of 30 lesions, which is a significant problem. In summary, cobalt alloy stents are safe and feasible to be used in carotid stenting, but the restenosis rate remains a concern.

With an increasing number of cases being reported, the safety, feasibility and complications after using cobalt alloy stents will need to be further analyzed in CAS in the future. 


\section{Nitinol Stents}

Nitinol is an alloy composed mostly of nickel-titanium as well as cobalt and other metal elements. Nitinol alloy is the material most commonly used in carotid stents nowadays, usually for self-expanding stents. Self-expanding nitinol stents are usually manufactured slightly larger than the size of the target vessel. After deployment, this results in a small, 'chronic' / constant outward force against the recoil pressure between the stent and the vessel wall. Nitinol stents have a high radial-resistive force against outside compression [18].

Nitinol stents have 2 unique merits: superelasticity and shape-memory properties [19]. The elastic deformation of stainless steel and cobalt alloys is limited to approximately $1 \%$ strain. Nitinol, on the other hand, can be elastically deformed up to about $10 \%$ strain in some cases. After being released, the elastic deformation can be fully recovered. That property is called superelasticity, thus providing nitinol stents with a better vessel wall-stent apposition. On the other hand, when stress is applied to a nitinol stent, it deforms/bends temporarily, adapting to a changing situation. Once the stress is released, the material recovers its original structure and shape. This property is called shape memory.

Compared with 316L stainless steel balloon-expandable stents, the nitinol self-expanding stents have a much lower elasticity and a remarkably higher yield to stress. A titanium-oxide layer can passively form on the surface of nitinol stents, making them corrosion resistant [20]. This adds to nitinol stents having a better biocompatibility than 316L stainless steel stents. In addition, nitinol produces fewer artifacts than stainless steel and reproduces better on MR images.

Nitinol stents have been successfully used in clinical practice. Phatouros et al. [21] and Drescher et al. [22] have used nitinol self-expanding (SMART) stents in the treatment of 4 and 13 patients, respectively. In Phatouros et al.'s cases, all procedures were successful $(<20 \%$ residual stenosis). There were no SMART stent-related complications. During the 6-month follow-up period, no transient ischemic attacks or new strokes took place, which means the patients remained symptom free. This shows that SMART stents are safe and feasible. In Drescher et al.'s cases, the stenosis was successfully reduced to an average of $2.8 \%(0-21)$. However, restenosis was found in 8 out of the 13 patients during the 6-month follow-up period. Apart from that, 1 patient experienced brief neurological symptoms during the intervention. No further complications occurred during follow-up. These cases also show that SMART stents are safe and feasible to use for treating carotid stenosis, but also that restenosis is a big problem to address. In another multicenter study, Qureshi et al. [23] analyzed 71 patients (73 lesions). Only 4 procedures were unsuccessful. The residual stenosis was reduced significantly in the other 69 lesions treated with nitinol Bard Memotherm stents. A total of 65 (89\%) of the 73 procedures meet the primary endpoint. One major ischemic stroke was found in 1 patient, and another patient died of intracerebral hemorrhage. The overall 1-month stroke rate was $2.7 \%$ for the 73 attempted procedures. This shows that Bard Memotherm stents can be used in the treatment of patients with coronary artery stenosis and are associated with a low peri-procedural complication rate.

However, nitinol stents also have some drawbacks, e.g. a weak radial-resistive force compared with 316L stainless steel stents, a low radio-opacity and a liability to fracture. Due to modifications to the surface [24] and other techniques, these drawbacks will soon be overcome. Additionally, a new stent design will lead to improvements in the radial-resistive force and other properties [25]. Markers like gold or tantalum are attached or integrated into the design of the stent to improve radio-opacity. With more and more techniques making use of this material, there will be a brighter tomorrow for nitinol stents.

Although a high initial success rate has been achieved with bare-metal stents, early and late complications including (sub)acute occlusion and neointimal hyperplasia resulting in the in-stent recurrence of stenosis (in-stent restenosis) is something that cannot be ignored. Researchers are working on strategies focused on these complications. 


\section{Coated Stents}

Coated stents are composed of a kind of stent material, usually bare metal, coated with another material on the surface. The coating material can be divided into passive and active coating [26]. Passive coating is based on gold, carbon, a polymer or ceramic coating. Active coating usually includes drugs, e.g. heparin or recombinant human thrombomodulin, which can interfere with the process of thrombosis and neointimal hyperplasia. Some believe that the coating can reduce metal ion release, neointimal hyperplasia, surface thrombogenicity and platelet activation and thus improve biocompatibility.

Unfortunately, the clinical results of coronary artery stenting could not always confirm its theoretical advantages [27]. The rates of thrombus formation and restenosis of coated stents were either higher than or equal to those of bare-metal stents. There are only animal data about coated stents used for carotid arteries. Some of the results are promising and some are not $[28,29]$. Maybe the passively coated stent (no drugs) is not ideal as carotid stent material.

\section{Radioactive Stents}

Radiotherapy has been proved to be successful in clinical experience to prevent in-stent restenosis of the carotid artery [30-32]. In Pokrajac et al.'s study [31], radiotherapy was given to 5 patients after carotid artery angioplasty. No acute side effects associated with radiotherapy were observed, which means all patients tolerated the treatment well. During the 4-month follow-up period, 2 patients were found with recurrence of stenosis. However, late total occlusion of the stent was noticed in all cases. Three patients remained symptom free with $<50 \%$ restenosis, 1 patient developed a severe stroke and the last patient died. This shows that radiotherapy is a feasible treatment option for highly selected patients with carotid artery in-stent restenosis. However, the application of radioactive stents has only been reported in animal carotid experiments [33], which showed promising results in suppressing neointimal formation.

One clinical trial attempted applying radioactive stents to coronary artery stenosis [34]; the results showed that in-stent neointimal hyperplasia was reduced in a dose-dependent manner. However, the rate of intralesional restenosis was high because of late lumen loss in the reference segments at the edges of the stents, called the candy wrapper effect.

Even though the future of radioactive stents is promising, due to the risk of late thrombosis and the candy wrapper effect, there is much work to be done before a clinical application of radioactive stents in carotid arteries is feasible.

\section{Drug-Eluting Stents}

The emergence of drug-eluting stents (DES) is a milestone in the history of stent development. There is hope to eliminate in-stent restenosis with DES. DES are stents bonding with drugs that are then constantly released to surrounding tissue. The difference between DES and drug-coated stents is that the drugs of DES can be constantly released to surrounding tissue. DES are composed of 3 basic parts: the bare metal, the drug delivery system and the drugs. There are 3 generations of DES on the market today [35]. The first-generation DES are made from a bare metal stent and a permanent polymer coating that has limited flexibility and is fairly plain. The second-generation DES are composed of durable coatings, which make them more biocompatible than first-generation DES. The third-generation DES show a strong 
focus on design and material, which makes them more flexible and highly deliverable. Some studies have experienced clinical success with DES in the carotid artery [36, 37]; the results showed that this generation of DES can effectively diminish restenosis rates.

The drugs within the DES should be effective but not toxic. The two most commonly used drugs are sirolimus and paclitaxel. Sirolimus is an immunosuppressive agent. It works by interacting with a specific target protein (mTOR, the mammalian target of rapamycin) and inhibiting its activation to block the G1-to-S cell cycle progression. The inhibition of mTOR suppresses cell proliferation. Sirolimus has also been reported to prevent neointimal formation through MAPK and NF- $\kappa \mathrm{B}$ pathways [38]. In animal experiments, sirolimuseluting stents reduced neointima significantly (5.9 \pm 2.5 vs. $\left.0.7 \pm 1.0 \mathrm{~mm}^{2}\right)$ compared with bare-metal stents [39]. This proves that sirolimus is effective in inhibiting neointimal formation. Paclitaxel is an antiproliferative agent. Pharmacologically, its effect is to allow the generation of numerous decentralized and unorganized microtubules. Thus, an assembly of extraordinarily stable microtubules will be enhanced, which interrupts proliferation, migration and signal transduction and can induce apoptotic cell death in a number of cell types [40]. In animal models, the neointimal area, the area of stenosis and the maximal neointimal thickness were significantly lower using paclitaxel-eluting stents than with referential bare-metal stents [41]. This shows that paclitaxel-eluting stents inhibit neointimal formation effectively.

Other candidate drugs for DES are zotarolimus, tacrolimus and fludarabine [42-44]. Dual DES ( 1 stent, 2 drugs) have been reported to reduce thrombosis and proliferation at the same time [45]. There are also studies of gene vector delivery for gene therapy based on this platform [46]. Both studies indicate a promising future for DES. Nevertheless, the possibility of late thrombosis, related to delayed re-endothelialization, has to be considered. Ma et al. [47] reported that the process of re-endothelialization could be ameliorated by glycogen synthase kinase- $3 \beta$ inhibitor treatment via enhancing the adhesion of endothelial progenitor cells. There will most certainly be more studies focusing on this problem in order to eliminate this Achilles' heel.

However, so far, clinical studies applying DES to the carotid artery are lacking. Further randomized studies are needed to examine the effectiveness, safety and complications of these devices.

DES mark a major step forward in the development of carotid stents. But as they are permanent devices in the body, there are still complications associated with them. These considerations drove researchers to find a material more compatible with the human body.

\section{Biodegradable Stents}

Although stents have been successfully used in the treatment of carotid stenosis, there are still some limitations to stents which remain to be resolved. The limitations of metallic stents are an impairment of the vessel's geometry, a mismatch of the stent to the vessel size and stent thrombosis, which requires prolonged antiplatelet therapy. DES are a breakthrough in the development of stents because of their ability to significantly reduce restenosis rates. But the possibility of subacute and late thrombosis associated with them is another problem to be addressed. Apart from that, permanent devices staying in the body can hinder future surgery or revascularization and can cause rejection at any time. However, biodegradable stents disappear within a limited time, and once biodegraded, a healed natural vessel with a chance of restoration of vasoreactivity will be achieved, including the potential of vessel remodeling. In that moment, patients will no longer have to worry about late stent thrombosis and will no longer need prolonged antiplatelet therapy, since the stent is gone [48]. 


\section{Polymer Stents}

Polymer stents are the first type of biodegradable stents ever used. The first polymer proposed for a biodegradable stent was poly-L-lactic acid (PLLA). Other polymers that have been suggested are polyglycolic acid, polycaprolactone and poly(D,L-lactide/glycolide) copolymer $[49,50]$. There have been clinical trials using biodegradable polymeric stents in the coronary artery showing their effectiveness and safety. However, so far there have only been animal experiments with polymeric stents in the carotid artery. Kischkel et al. [51] implanted a novel biodegradable stent based on PLLA and poly-4-hydroxybutyrate into the porcine carotid artery. Their PLLA/poly-4-hydrocybutyrate stent group showed a decreased residual luminal area and higher restenosis but a lower vascular injury score than the 316L stainless steel reference group, which means the novel stents have a good biocompatibility but the high restenosis rates are a serious problem.

There are still limitations to polymer stents, e.g. their lower strength compared to metallic stents, local inflammation and restenosis rates $[48,49]$. Further studies are needed to resolve these limitations.

\section{Magnesium Alloy Stents}

Magnesium is the fourth most plentiful cation in the body, and people have studied its biological role extensively. The concentration of magnesium released from a stent is extremely low compared to the physiological magnesium content in the plasma $(0.70-1.05 \mathrm{mmol} / \mathrm{l})$. A magnesium alloy is expected to satisfy most requirements of a biodegradable vascular stent, such as mechanical properties, biocompatibility and degradation/absorption performance. In a prospective, multicenter, clinical trial, magnesium stents have been implanted into 63 patients with de novo coronary lesions [52]. An immediate angiographic result similar to that of other metal stents was achieved, and the stents were safely degraded after 4 months. However, the degradation rate was higher than expected. Lu et al. [53] controlled the corrosion resistance and the biodegradation rate by fabricating a micro-arc oxidation/PLLA coating on the magnesium alloy AZ81 substrate. Another study showed that by the addition of alloying elements, especially rare earth elements and other metallic elements including calcium, lithium and zirconium, the mechanical properties and corrosion resistance of magnesium alloys can be improved [54]. However, there are no studies on the application of magnesium alloy stents to the carotid artery.

\section{Iron Alloy Stents}

Iron is another essential element in the human body, meaning a release of iron ions from stents is not toxic to surrounding tissue. Iron alloy (Fe-based alloy) stents have a high radial strength because of their higher elasticity. This can be helpful when making stents with thinner struts. The first iron stents produced from pure iron were implanted into the native descending aorta of 16 New Zealand white rabbits [55]. This resulted in no thromboembolic complications, no pronounced inflammatory response, no significant neointimal proliferation and no systemic toxicity. Wu et al. [56] implanted iron stents into mini-swine coronary arteries. As a result, the mean neointimal thickness, neointimal area, percentage of area stenosis and intimal injury scores were not significantly different between the iron stents and the cobalt chromium reference stents. Those studies showed that iron-based stents have a good biocompatibility and short-term safety and efficacy. But the low degradation rate is a big problem. In Huang et al.'s study [57], iron-5 wt\% palladium and iron-5 wt $\%$ platinum composites were tested. The results showed that the degradation rates of the iron-palladium and the iron-platinum composites were much faster than that of pure iron. Another study showed that microstructural modifications can change the degradation rate [54]. Once the degradation rate is appropriate, iron alloy stents will be perfect biodegradable stents. Nevertheless, there have been no studies on iron alloy stents in the carotid artery so far. 


\section{The Aim}

The ideal biodegradable stent should: (1) be biocompatible, and the degradation products of the material must also be biocompatible; (2) stay in place for 6-12 months before it is completely biodegraded and still have enough radial force for a scaffolding effect during the requested period, and (3) have ideal degradation rates, be completely degraded after 6-12 months, allowing positive artery remodeling [58]. Today, no available stent meets these standards. When the limitations of polymers and the degradation rates of magnesium and iron are 'solved problems', these biodegradable stents will most likely be ideal stents.

Even though there have only been animal experiments with polymer stents in the carotid artery so far [51, 59], biodegradable stents will be the ideal stents in the future considering the advantages they have. We need more studies to analyze the safety, feasibility and limitations of biodegradable stents in the carotid artery before their clinical application.

\section{Stent Design}

There is also the aspect of stent design. Stents can be divided into balloon-expandable and self-expanding stents; the characteristics have been described previously. The raw material includes sheets, wires and tubes. Stents can be fabricated by coiling, braiding, knitting, laser cutting or water-jet cutting. Meanwhile, photochemical etching is another new method for stent fabrication. The geometry of stents includes coils and helical spirals as well as woven, individual and sequential rings. In detail, open-cell and closed-cell stents are subcategories of sequential rings. Open-cell stents describe constructions where none or only some of the internal inflection points of the structural members are connected by bridging elements. In contrast, closed-cell stents are of the kind that all internal inflection points of the structural members are connected by bridging elements $[11,60]$.

Based on different aspects of design, stents will have different performances. For example, a heat-affected zone along the cut edge will show up in laser-cut products but not in waterjet-cut products. Both coil stents and helical-spiral stents are extremely flexible, but coil stents are high-profile devices, while helical-spiral stents show a lack in longitudinal support. Woven stents offer excellent coverage, but they shrink during expansion. Open-cell stents are more flexible than closed-cell ones; however, closed-cell stents have an optimal scaffolding property and a uniform surface, regardless of the degree of bending.

Apart from their different performance based on engineering, stents with different designs result in different clinical features [11]. Neointimal hyperplasia can be influenced by stent design, as has been shown in animal models. Different vessels and lesions need different stents. Tortuous lesions require particularly flexible and conformable stents. Stents with strong radial support and good radiological visibility are needed in ostial lesions. Bifurcational lesions need stents with large side openings that permit the passage of a second stent or a balloon, and small vessels prefer flexible stents with a thin strut structure. There are also studies showing that different stent designs can influence the wall-rheological characteristics, hemodynamic performance, degree of platelet activation [61] and stent thrombosis. Numerous trials have shown that tubular and multicellular stents produce better results than wire mesh and coil stents concerning thrombosis and restenosis in the coronary artery [6264]. There are also other trials on stenting the coronary artery which proved that there are more vascular injuries, more intimal hyperplasia and a higher risk for restenosis using stents with thicker struts than thinner struts [65-67].

The material, raw material forms, fabrication methods and geometry are all important aspects of stent design. They can influence clinical results in different ways. Only when all of them are considered properly, stents suitable for clinical use can be manufactured. 
Table 1. The characteristics of the stent materials reviewed

\begin{tabular}{|c|c|c|c|}
\hline & Merits & Drawbacks & Application proofs \\
\hline \multicolumn{4}{|l|}{ Bare-metal stents } \\
\hline Stainless steel & $\begin{array}{l}\text { high strength and radio force, } \\
\text { good biocompatibility }\end{array}$ & $\begin{array}{l}\text { low MR compatibility, low } \\
\text { corrosion resistance, bad } \\
\text { vessel wall-stent apposition }\end{array}$ & clinical data \\
\hline Cobalt alloy & $\begin{array}{l}\text { high strength and radio-opacity, } \\
\text { good corrosion resistance, } \\
\text { biocompatibility }\end{array}$ & restenosis & clinical data \\
\hline Nitinol & $\begin{array}{l}\text { superelasticity and shape } \\
\text { memory property, } \\
\text { biocompatibility }\end{array}$ & $\begin{array}{l}\text { weak radial-resistive force, } \\
\text { low radio-opacity, fracture }\end{array}$ & clinical data \\
\hline Radioactive stents & prevent restenosis & $\begin{array}{l}\text { candy wrapper effect, late } \\
\text { thrombosis }\end{array}$ & $\begin{array}{l}\text { animal experiment } \\
\text { data }\end{array}$ \\
\hline Drug-eluting stents & reduce restenosis rate & $\begin{array}{l}\text { late thrombosis, stay } \\
\text { permanently in the body }\end{array}$ & clinical data \\
\hline \multicolumn{4}{|l|}{ Biodegradable stents } \\
\hline Polymer(s) & disappear after several months & $\begin{array}{l}\text { lower strength, local } \\
\text { inflammation, restenosis }\end{array}$ & $\begin{array}{l}\text { animal experiment } \\
\text { data }\end{array}$ \\
\hline Magnesium alloy & disappear after several months & degrade too fast & $\begin{array}{l}\text { no data on carotid } \\
\text { artery }\end{array}$ \\
\hline Iron alloy & disappear after several months & degrade too slowly & $\begin{array}{l}\text { no data on carotid } \\
\text { artery }\end{array}$ \\
\hline
\end{tabular}

\section{Future Perspectives}

Bare-metal stents have a decent scaffolding strength and can prevent early vessel recoil, but they may result in thrombosis and restenosis. DES are a breakthrough in the development of stents because of their ability to significantly reduce restenosis rates. However, the subacute and late thrombosis rates associated with them are a problem to be addressed. Biodegradable stents disappear after they have served their function, and this seems to be the ideal option for stent development. However, the biodegradable polymers have unacceptable restenosis rates, and the degradation rates of biodegradable metal stents remain to be studied. The characteristics of every material are showed in table 1.

There have been reports of a hybrid stent, which is a combination of a biodegradable stent and a DES [68-71]. These stents are antiproliferative, have an anticoagulative effect and are anti-inflammatory; additionally, they disappear after having fulfilled their purpose. These stents have the potential to be ideal stents.

The ideal stent should (1) have a good biocompatibility and be nontoxic to the body, (2) be able to cure the carotid stenosis effectively and (3) result in no complications and not hinder surgery or other operations in the future [11]. There is no stent today that could cover all of these aspects. Looking at studies coming up now, we have good reason to believe that there will be a perfect material for an ideal stent in the future, which will cure more patients and give them a better life.

\section{Disclosure Statement}

The authors declare that they have no conflicts of interest. 
He et al.: The Development of Carotid Stent Material

\section{References}

1 Bonati LH, Engelter ST, Lyrer PA: Carotid artery stenting. Swiss Med Wkly 2012;142:w13619.

-2 Skerritt MR, Block RC, Pearson TA, Young KC: Carotid endarterectomy and carotid artery stenting utilization trends over time. BMC Neurol 2012;12:17.

-3 Wholey MH, Wholey MH: History and current status of endovascular management for the extracranial carotid and supra-aortic vessels. J Endovasc Ther 2004;11(suppl 2):II43-II61.

4 Brott TG, Hobson RW, Howard G, Roubin GS, Clark WM, Brooks W, Mackey A, Hill MD, Leimgruber PP, Sheffet AJ: Stenting versus endarterectomy for treatment of carotid-artery stenosis. N Engl J Med 2010;363:11-23.

5 Gray WA, Hopkins LN, Yadav S, Davis T, Wholey M, Atkinson R, Cremonesi A, Fairman R, Walker G, Verta P, Popma J, Virmani R, Cohen DJ: Protected carotid stenting in high-surgical-risk patients: the ARCHeR results. J Vasc Surg 2006;44:258-268.

6 Xu G, Zhu J, Liu X: Stratifying carotid diseases for endovascular treatments. Interv Neurol 2012;1:16-21.

7 Yadav JS, Wholey MH, Kuntz RE, Fayad P, Katzen BT, Mishkel GJ, Bajwa TK, Whitlow P, Strickman NE, Jaff MR, Popma JJ, Snead DB, Cutlip DE, Firth BG, Ouriel K: Protected carotid-artery stenting versus endarterectomy in high-risk patients. N Engl J Med 2004;351:1493-1501.

8 Colley R, Yan B: Genetic determinations of variable responsiveness to clopidogrel and implications for neurointerventional procedures. Interv Neurol 2012;1:22-30.

-9 Wasser K, Schnaudigel S, Wohlfahrt J, Psychogios MN, Knauth M, Groschel K: Inflammation and in-stent restenosis: the role of serum markers and stent characteristics in carotid artery stenting. PLoS One 2011;6:e22683.

10 Haidopoulos M, Turgeon S, Sarra-Bournet C, Laroche G, Mantovani D: Development of an optimized electrochemical process for subsequent coating of 316 stainless steel for stent applications. J Mater Sci Mater Med 2006;17:647-657.

11 Sangiorgi G, Melzi G, Agostoni P, Cola C, Clementi F, Romitelli P, Virmani R, Colombo A: Engineering aspects of stents design and their translation into clinical practice. Ann Ist Super Sanita 2007;43:89-100.

-12 Mukherjee D, Kalahasti V, Roffi M, Bhatt DL, Kapadia SR, Bajzer C, Reginelli J, Ziada KM, Hughes K, Yadav JS: Self-expanding stents for carotid interventions: comparison of nitinol versus stainless-steel stents. J Invasive Cardiol 2001;13:732-735.

13 Sheth S, Litvack F, Dev V, Fishbein MC, Forrester JS, Eigler N: Subacute thrombosis and vascular injury resulting from slotted-tube nitinol and stainless steel stents in a rabbit carotid artery model. Circulation 1996;94:17331740.

14 Li L, Pan S, Zhou X, Meng X, Han X, Ren Y, Yang K, Guan Y: Reduction of in-stent restenosis risk on nickel-free stainless steel by regulating cell apoptosis and cell cycle. PLoS One 2013;8:e62193.

15 O'Brien B, Carroll W: The evolution of cardiovascular stent materials and surfaces in response to clinical drivers: a review. Acta Biomater 2009;5:945-958.

-16 Tanaka N, Martin JB, Tokunaga K, Abe T, Uchiyama Y, Hayabuchi N, Berkefeld J, Rufenacht DA: Conformity of carotid stents with vascular anatomy: evaluation in carotid models. AJNR Am J Neuroradiol 2004;25:604-607.

17 Vajda Z, Miloslavski E, Guthe T, Schmid E, Schul C, Albes G, Henkes H: Treatment of intracranial atherosclerotic arterial stenoses with a balloon-expandable cobalt chromium stent (Coroflex Blue): procedural safety, efficacy, and midterm patency. Neuroradiology 2010;52:645-651.

18 Duerig T, Pelton A, Stöckel D: An overview of nitinol medical applications. Mater Sci Eng A 1999;273-275: 149-160.

19 Stoeckel D, Pelton A, Duerig T: Self-expanding nitinol stents: material and design considerations. Eur Radiol 2004;14:292-301.

20 Shabalovskaya SA: Surface, corrosion and biocompatibility aspects of Nitinol as an implant material. Biomed Mater Eng 2002;12:69-109.

21 Phatouros CC, Higashida RT, Malek AM, Meyers PM, Lempert TE, Dowd CF, Halbach VV: Endovascular stenting for carotid artery stenosis: preliminary experience using the shape-memory-alloy-recoverable-technology (SMART) stent. AJNR Am J Neuroradiol 2000;21:732-738.

-22 Drescher R, Mathias KD, Jaeger HJ, Bockisch G, Demirel E, Gissler HM, Hauth E: Clinical results of carotid artery stenting with a nitinol self-expanding stent (SMART stent). Eur Radiol 2002;12:2451-2456.

23 Qureshi AI, Suri MF, New G, Wadsworth DC Jr, Dulin J, Hopkins LN: Multicenter study of the feasibility and safety of using the memotherm carotid arterial stent for extracranial carotid artery stenosis. J Neurosurg 2002;96:830-836.

24 Shabalovskaya S, Anderegg J, Van Humbeeck J: Critical overview of Nitinol surfaces and their modifications for medical applications. Acta Biomater 2008;4:447-467.

25 Wu W, Qi M, Liu XP, Yang DZ, Wang WQ: Delivery and release of nitinol stent in carotid artery and their interactions: a finite element analysis. J Biomech 2007;40:3034-3040.

26 Wieneke H, Sawitowski T, Wnendt S, Fischer A, Dirsch O, Karoussos IA, Erbel R: Stent coating: a new approach in interventional cardiology. Herz 2002;27:518-526.

-27 Lau KW, Mak KH, Hung JS, Sigwart U: Clinical impact of stent construction and design in percutaneous coronary intervention. Am Heart J 2004;147:764-773.

28 Lin PH, Chronos NA, Marijianowski MM, Chen C, Conklin B, Bush RL, Lumsden AB, Hanson SR: Carotid stenting using heparin-coated balloon-expandable stent reduces intimal hyperplasia in a baboon model. J Surg Res 2003;112:84-90. 
He et al.: The Development of Carotid Stent Material

-29 Rechavia E, Litvack F, Fishbien MC, Nakamura M, Eigler N: Biocompatibility of polyurethane-coated stents: tissue and vascular aspects. Cathet Cardiovasc Diagn 1998;45:202-207.

30 Chan AW, Roffi M, Mukherjee D, Bajzer CT, Abou-Chebl A, Ciezki J, Bhatt DL, Ghaffari S, Yadav JS: Carotid brachytherapy for in-stent restenosis. Catheter Cardiovasc Interv 2003;58:86-92.

31 Pokrajac B, Ahmadi R, Schmid R, Schillinger M, Kirisits C, Minar E, Potter R: 3D-conformal radiotherapy for prevention of carotid recurrent in-stent restenosis. Initial experience. Wien Klin Wochenschr 2005;117:293-296.

-32 Seemann JH, Leppien A, Feyer P, Felix R: Peripheral vascular disease: carotid and vertebral brachytherapy for in-stent restenosis. Catheter Cardiovasc Interv 2005;65:412-415.

-33 Rosenthal D, Stevens SL, Skillern CS, Wellons ED, Robinson K, Matsuura JH, Gannon BJ: Topical application of beta-radiation to reduce intimal hyperplasia after carotid artery balloon injury in rabbit. A possible application for brachytherapy in vascular surgery. Cardiovasc Radiat Med 2002;3:16-19.

-34 Albiero R, Adamian M, Kobayashi N, Amato A, Vaghetti M, Di Mario C, Colombo A: Short- and intermediateterm results of ${ }^{32} \mathrm{P}$ radioactive beta-emitting stent implantation in patients with coronary artery disease: the Milan Dose-Response Study. Circulation 2000;101:18-26.

-35 von Birgelen C, Sen H, Lam MK, Danse PW, Jessurun GA, Hautvast RW, van Houwelingen GK, Schramm AR, Gin RM, Louwerenburg JW, de Man FH, Stoel MG, Lowik MM, Linssen GC, Said SA, Nienhuis MB, Verhorst PM, Basalus MW, Doggen CJ, Tandjung K: Third-generation zotarolimus-eluting and everolimus-eluting stents in all-comer patients requiring a percutaneous coronary intervention (DUTCH PEERS): a randomised, singleblind, multicentre, non-inferiority trial. Lancet 2014;383:413-423.

-36 Gupta R, Al-Ali F, Thomas AJ, Horowitz MB, Barrow T, Vora NA, Uchino K, Hammer MD, Wechsler LR, Jovin TG: Safety, feasibility, and short-term follow-up of drug-eluting stent placement in the intracranial and extracranial circulation. Stroke 2006;37:2562-2566.

-37 Tekieli L, Pieniazek P, Musialek P, Kablak-Ziembicka A, Przewlocki T, Trystula M, Moczulski Z, Dzierwa K, Paluszek P, Podolec P: Zotarolimus-eluting stent for the treatment of recurrent, severe carotid artery in-stent stenosis in the TARGET-CAS population. J Endovasc Ther 2012;19:316-324.

-38 Omura T, Yoshiyama M, Izumi Y, Kim S, Matsumoto R, Enomoto S, Kusuyama T, Nishiya D, Nakamura Y, Akioka $\mathrm{K}$, Iwao $\mathrm{H}$, Takeuchi $\mathrm{K}$, Yoshikawa J: Involvement of c-Jun NH2 terminal kinase and p38MAPK in rapamycinmediated inhibition of neointimal formation in rat carotid arteries. J Cardiovasc Pharmacol 2005;46:519-525.

-39 Tepe G, Muschick P, Laule M, Reddig F, Claussen CD, Dinkelborg LM, Tielemans H, Wehrmann M, Duda SH: Prevention of carotid artery restenosis after sirolimus-coated stent implantation in pigs. Stroke 2006;37: 492-494.

40 Regar E, Sianos G, Serruys PW: Stent development and local drug delivery. Br Med Bull 2001;59:227-248.

-41 Schwarzmaier-D’Assie A, Nyolczas N, Hemetsberger R, Strehblow C, Matiasek J, Farhan S, Petrasi Z, Huber K, Wojta J, Glogar D, Plass C, Gyongyosi M, Karnik R: Comparison of short- and long-term results of drug-eluting vs. bare metal stenting in the porcine internal carotid artery. J Endovasc Ther 2011;18:547-558.

-42 Camici GG, Steffel J, Amanovic I, Breitenstein A, Baldinger J, Keller S, Luscher TF, Tanner FC: Rapamycin promotes arterial thrombosis in vivo: implications for everolimus and zotarolimus eluting stents. Eur Heart J 2010;31:236-242.

43 Torella D, Curcio A, Gasparri C, Galuppo V, De Serio D, Surace FC, Cavaliere AL, Leone A, Coppola C, Ellison GM, Indolfi C: Fludarabine prevents smooth muscle proliferation in vitro and neointimal hyperplasia in vivo through specific inhibition of STAT-1 activation. Am J Physiol Heart Circ Physiol 2007;292:H2935-H2943.

44 Wieneke H, Dirsch O, Sawitowski T, Gu YL, Brauer H, Dahmen U, Fischer A, Wnendt S, Erbel R: Synergistic effects of a novel nanoporous stent coating and tacrolimus on intima proliferation in rabbits. Catheter Cardiovasc Interv 2003;60:399-407.

-45 Huang Y, Venkatraman SS, Boey FY, Lahti EM, Umashankar PR, Mohanty M, Arumugam S, Khanolkar L, Vaishnav S: In vitro and in vivo performance of a dual drug-eluting stent (DDES). Biomaterials 2010;31:43824391.

-46 Fishbein I, Alferiev IS, Nyanguile O, Gaster R, Vohs JM, Wong GS, Felderman H, Chen IW, Choi H, Wilensky RL, Levy RJ: Bisphosphonate-mediated gene vector delivery from the metal surfaces of stents. Proc Natl Acad Sci USA 2006;103:159-164.

-47 Ma X, Hibbert B, Dhaliwal B, Seibert T, Chen YX, Zhao X, O’Brien ER: Delayed re-endothelialization with rapamycin-coated stents is rescued by the addition of a glycogen synthase kinase-3beta inhibitor. Cardiovasc Res 2010;86:338-345.

48 Waksman R: Update on bioabsorbable stents: from bench to clinical. J Interv Cardiol 2006;19:414-421.

49 Erne P, Schier M, Resink TJ: The road to bioabsorbable stents: reaching clinical reality? Cardiovasc Intervent Radiol 2006;29:11-16.

50 Peng T, Gibula P, Yao KD, Goosen MF: Role of polymers in improving the results of stenting in coronary arteries. Biomaterials 1996;17:685-694.

51 Kischkel S, Grabow N, Kabelitz M, Erdle B, Schareck W, Martin DP, Williams SF, Sternberg K, Schmitz KP, Bunger CM: Biocompatibility of biodegradable polymeric stents in an interventional porcine carotid artery model. Biomed Tech (Berl) 2012, DOI: 10.1515/bmt-2012-4232.

52 Erbel R, Di Mario C, Bartunek J, Bonnier J, de Bruyne B, Eberli FR, Erne P, Haude M, Heublein B, Horrigan M, Ilsley C, Bose D, Koolen J, Luscher TF, Weissman N, Waksman R: Temporary scaffolding of coronary arteries with bioabsorbable magnesium stents: a prospective, non-randomised multicentre trial. Lancet 2007;369: 1869-1875. 
-53 Lu P, Fan H, Liu Y, Cao L, Wu X, Xu X: Controllable biodegradability, drug release behavior and hemocompatibility of PTX-eluting magnesium stents. Colloids Surf B Biointerfaces 2011;83:23-28.

54 Moravej M, Mantovani D: Biodegradable metals for cardiovascular stent application: interests and new opportunities. Int J Mol Sci 2011;12:4250-4270.

55 Peuster M, Wohlsein P, Brugmann M, Ehlerding M, Seidler K, Fink C, Brauer H, Fischer A, Hausdorf G: A novel approach to temporary stenting: degradable cardiovascular stents produced from corrodible metal-results 6-18 months after implantation into New Zealand white rabbits. Heart 2001;86:563-569.

-56 Wu C, Qiu H, Hu XY, Ruan YM, Tian Y, Chu Y, Xu XL, Xu L, Tang Y, Gao RL: Short-term safety and efficacy of the biodegradable iron stent in mini-swine coronary arteries. Chin Med J (Engl) 2013;126:4752-4757.

57 Huang T, Cheng J, Zheng YF: In vitro degradation and biocompatibility of Fe-Pd and Fe-Pt composites fabricated by spark plasma sintering. Mater Sci Eng C Mater Biol Appl 2014;35:43-53.

58 Sharkawi T, Cornhill F, Lafont A, Sabaria P, Vert M: Intravascular bioresorbable polymeric stents: a potential alternative to current drug eluting metal stents. J Pharm Sci 2007;96:2829-2837.

59 Zamiri P, Kuang Y, Sharma U, Ng TF, Busold RH, Rago AP, Core LA, Palasis M: The biocompatibility of rapidly degrading polymeric stents in porcine carotid arteries. Biomaterials 2010;31:7847-7855.

60 Stoeckel D, Bonsignore C, Duda S: A survey of stent designs. Minim Invasive Ther Allied Technol 2002;11: 137-147.

61 Gurbel PA, Callahan KP, Malinin AI, Serebruany VL, Gillis J: Could stent design affect platelet activation? Results of the Platelet Activation in STenting (PAST) Study. J Invasive Cardiol 2002;14:584-589.

62 Kastrati A, Dirschinger J, Boekstegers P, Elezi S, Schuhlen H, Pache J, Steinbeck G, Schmitt C, Ulm K, Neumann FJ, Schomig A: Influence of stent design on 1-year outcome after coronary stent placement: a randomized comparison of five stent types in 1,147 unselected patients. Catheter Cardiovasc Interv 2000;50:290-297.

63 Lansky AJ, Roubin GS, O’Shaughnessy CD, Moore PB, Dean LS, Raizner AE, Safian RD, Zidar JP, Kerr JL, Popma JJ, Mehran R, Kuntz RE, Leon MB: Randomized comparison of GR-II stent and Palmaz-Schatz stent for elective treatment of coronary stenoses. Circulation 2000;102:1364-1368.

-64 Thuesen L, Andersen HR, Krusell LR, Botker HE, Jorgensen E, Kelbaek H, Kristensen SD: Randomized comparison of the coil-design Crossflex and the tubular NIR stent. Catheter Cardiovasc Interv 2003;59:8-12.

65 Briguori C, Sarais C, Pagnotta P, Liistro F, Montorfano M, Chieffo A, Sgura F, Corvaja N, Albiero R, Stankovic G, Toutoutzas C, Bonizzoni E, Di Mario C, Colombo A: In-stent restenosis in small coronary arteries: impact of strut thickness. J Am Coll Cardiol 2002;40:403-409.

-66 Kastrati A, Mehilli J, Dirschinger J, Dotzer F, Schuhlen H, Neumann FJ, Fleckenstein M, Pfafferott C, Seyfarth M, Schomig A: Intracoronary stenting and angiographic results: strut thickness effect on restenosis outcome (ISAR-STERE0) trial. Circulation 2001;103:2816-2821.

67 Pache J, Kastrati A, Mehilli J, Schuhlen H, Dotzer F, Hausleiter J, Fleckenstein M, Neumann FJ, Sattelberger U, Schmitt C, Muller M, Dirschinger J, Schomig A: Intracoronary stenting and angiographic results: strut thickness effect on restenosis outcome (ISAR-STEREO-2) trial. J Am Coll Cardiol 2003;41:1283-1288.

68 Bunger CM, Grabow N, Sternberg K, Kroger C, Ketner L, Schmitz KP, Kreutzer HJ, Ince H, Nienaber CA, Klar E, Schareck W: Sirolimus-eluting biodegradable poly-L-lactide stent for peripheral vascular application: a preliminary study in porcine carotid arteries. J Surg Res 2007;139:77-82.

69 Tsuji T, Tamai H, Igaki K, Kyo E, Kosuga K, Hata T, Nakamura T, Fujita S, Takeda S, Motohara S, Uehata H: Biodegradable stents as a platform to drug loading. Int J Cardiovasc Intervent 2003;5:13-16.

70 Vogt F, Stein A, Rettemeier G, Krott N, Hoffmann R, vom Dahl J, Bosserhoff AK, Michaeli W, Hanrath P, Weber C, Blindt R: Long-term assessment of a novel biodegradable paclitaxel-eluting coronary polylactide stent. Eur Heart J 2004;25:1330-1340.

-71 Yamawaki T, Shimokawa H, Kozai T, Miyata K, Higo T, Tanaka E, Egashira K, Shiraishi T, Tamai H, Igaki K, Takeshita A: Intramural delivery of a specific tyrosine kinase inhibitor with biodegradable stent suppresses the restenotic changes of the coronary artery in pigs in vivo. J Am Coll Cardiol 1998;32:780-786. 